Original research article

\title{
Questionnaire survey: The process of quality management in the preanalytical phase of laboratory examination in the department of joint laboratories
}

\author{
Iveta Slabíková ${ }^{1}$, Lada Nováková ${ }^{2}$, Lada Cetlová ${ }^{2}$, Vlasta Dvořáková ${ }^{2}$, Andrea Pokorná ${ }^{2,3 *}$ \\ ${ }^{1}$ Hospital of Havličkův Brod, Havličkův Brod, Czech Republic \\ ${ }^{2}$ College of Polytechnics Jihlava, Jihlava, Czech Republic \\ ${ }^{3}$ Masaryk University, Faculty of Medicine, Department of Nursing and Midwifery, Brno, Czech Republic
}

\begin{abstract}
Introduction: Preparation of a patient for an examination and taking samples of biological material belong to critical factors of the laboratory preanalytical phase's quality. Taking of venous blood is one of the most common nursing care interventions.

Methods: A questionnaire survey using a content validated questionnaire from the laboratory of clinical biochemistry of University hospital in Umeå in Sweden has been carried out. Data analysis was performed using the Statistics 12 program at a significance level of 0.05 .

Aim: The main aim was to evaluate a selected group of general nurses' awareness about the correct procedures for collecting venous blood in two accredited inpatient health care providers.

Results: One-hundred-and-fifty-three general nurses from two health care facilities took part in the study (hospital A: $n=71$, hospital B: $n=82$ ). The answers of the general nurses from both monitored facilities were almost identical, but not always correct. There was a statistically insignificant difference $(p<0.05)$ in the knowledge of general nurses in the procedure of venous blood collection. Still, there was a statistically significant difference in the declared labeling of tubes before collecting or in the collection of several different tubes at once $(p<0.05)$.

Conclusions: The identified inconsistencies in the procedures during blood taking conform to previous foreign studies. The need for close collaboration with clinical laboratory personnel and the requirement of control in the preanalytical phase concerning taking samples of biological material is essential to ensure better quality care.
\end{abstract}

Keywords: General nurse; Health care risk; Patient safety; Preanalytical phase; Venous blood collection

\section{Introduction}

The services provided by clinical laboratories form an integral part of comprehensive medical services. The laboratory meets clinical workplace requirements and produces results for patients whose health services are primarily intended (Plebani, 2009; Sciacovelli and Plebani, 2009). International studies suggest that most laboratory medicine errors are linked to the preanalytical phase i.e., before the sample is analyzed in a laboratory. Analytical errors (within the laboratory) and post-analytical errors (reporting and interpretation of results) are less frequent (Bölenius et al., 2012). This relates to Lundberg's concept for laboratory testing, called the "Brain-to-brain loop concept", i.e., the concept "from the brain to the brain". The concept stresses that the chain is only as strong as its weakest link. This represents everything that interferes with the complete closure of the loop for each laboratory test. Each weakest link can have a negative effect on the accuracy of the labora- tory result. Although this is a concept that is many years old, it is still realistic and, at the same time, a comprehensive view of the importance of laboratory testing. Both critical points of the whole loop are not missing - the evaluation of the patient's condition with the idea of selecting an appropriate "question" test, and the whole laboratory process with the result of measurements in the laboratory followed by a clinical decision "action" (Lundberg, 1990). Over time, both critical points have been considered concerning the proportion of errors in the various stages of the investigation process.

The introduction of the whole concept led to a system for identifying and classifying errors associated with the laboratory test. The laboratory process was divided into three phases, and the errors associated with them have since been considered preanalytical, analytical, and post-analytical (Lundberg, 1990). Laboratory medicine is an area where the same high demands are placed in higher patient safety as on the provision of care itself - the nursing and treatment process. Errors are the cause of the phenomena that threaten the safety of

\footnotetext{
* Corresponding author: Andrea Pokorná, Masaryk University, Faculty of Medicine, Department of Nursing and Midwifery, Kamenice 3, 62500 Brno, Czech Republic; e-mail: apokorna@med.muni.cz http://doi.org/10.32725/kont.2021.003 
processes the most. The patient's preparation for examining and collecting biological material is critical to the quality of the laboratory preanalytical phase. In the preanalytical phase, errors are caused by the inappropriate selection of tests, incorrect identification of the patient, incorrect collection of biological material, inappropriate handling of samples, uncontrolled transport, and improper storage. Surprisingly, up to 50-70\% of errors occur in the preanalytical phase of the laboratory examination - which occurs outside the laboratory (Jabor and Franeková, 2013). The human factor primarily causes preanalytical errors, and many of them can be prevented. The preanalytical phase is much more dependent on human manipulation than the analytical and post-analytical phases (Rana, 2012).

The harmonization of the preanalytical phase of laboratory tests should ensure the international recommendation for venous blood sampling, published electronically in June 2018 in the Journal of Clinical Chemistry and Laboratory Medicine. The analytical group EFLM (European Federation of Clinical Chemistry and Laboratory Medicine) and COLABIOCLI (Latin America Confederation of Clinical Biochemistry) participated in its elaboration. The recommendation covers all preanalytical processes, including their management, quality control, and education. It is an essential tool for achieving healthcare quality that closely links to laboratory services (Friedecký, 2018). The NCO NZO (Národní centrum ošetřovatelství a nelékařských zdravotnických oborů - National Center for Nursing and Non-Medical Health Professions in Brno) also deals with the issue of the correct preanalytical phase, and has prepared recommendations for the correct collection of venous blood and presents them on its website (Loosová et al., 2018). The task of clinical laboratories that operate a quality system is to ensure continuous improvement of the quality of the entire laboratory process and actively participate in quality health care in their clinical laboratory services. The ISO 15189: 2013 accreditation standard obliges laboratories to define preanalytical procedures regarding sampling, the type of collection kit, and instructions for educating patients before collection. The guidelines are individual and specific to each test (Kratochvíl et al., 2013). Interference effects for a given sample can only be detected during laboratory analysis or clinical interpretation. Part of the laboratories'controlled documentation is the Laboratory Manual, in which the applicant for laboratory examination will find the necessary information regarding the preanalytical phase. The venous blood specimen collection (VBSC) is one of the most common nursing care procedures (Fang et al., 2008). It is a comprehensive procedure that demands theoretical knowledge and manual skills, accuracy, ability, good caring conduct, and good interaction between the nurses doing phlebotomy and the patient. It is a basis for diagnosis and treatments (Plebani, 2009). Therefore, nurses' practices related to blood collection should strictly follow guidelines based on evidence and best practices (Fang et al., 2008; Grissinger, 2014; Rana, 2012).

\section{Goals}

The main goal was to determine the awareness of a selected group of general nurses about the correct procedures for collecting venous blood in two accredited inpatient health care providers (from now on referred to as hospitals A and B).

\section{Materials and methods}

A questionnaire study using a standardized, content-verified questionnaire for the assessment of venous blood sampling procedures. To obtain the full version of the questionnaire used and for permission to use it, we asked Professor Karin Bölenius from the Department of Nursing, Umeå University in Sweden, which researches primary care, nursing science, and clinical biochemistry. The verification of the questionnaire's content was based on interviews between a group of experts, including researchers, general nurses, biomedical technicians, heads of clinical laboratory departments, university and hospital physicians, and questionnaire development researchers in Sweden. To the best of the original questionnaire author's knowledge, no other instrument or standard existed to measure practical VBS. The test-retest analysis demonstrated that the items were generally stable. In total, $82 \%$ of the items fulfilled the reliability acceptance criteria: $\mathrm{K} \geq 0.61$ (Bölenius et al., 2012). The questionnaire contained a total of 19 questions. The first six items examined the essential characteristics of the respondents. Five questions reviewed the identification and sampling method, and two questions focused on storing samples and retrieving information for collection. One question concerned the disinfection of the injection site, and two questions concerned the time of collection and requests for laboratory tests. The frequency of reports and suggestions for errors represented three issues (Bölenius et al., 2012). The questionnaire was translated into $C$ zech by double translation (forward and backward translation process). After the pilot study (including 25 nurses), the printed questionnaires were distributed to the two hospitals. Both hospitals use the services of the same laboratory. The management of both hospitals declare identical instructions for performing the preanalytical phase of laboratory examinations. The conditions for carrying out the study could, therefore, be considered comparable. Hospital A had 540 beds and 23 wards, while Hospital B had 700 beds and 23 wards. The researcher selected these hospitals since they were of comparable size and were judged to represent the Czech Republic's average hospital under the same accreditation process. The data collection was carried out for a six-month period in 2018.

Data analysis was performed using the Statistica 12 program at the significance level $\alpha=0.05$. Pearson's chi-square test $\chi^{2}$ was chosen to determine the interdependence of individual variables used in hypothesis testing.

\section{Characteristics of the research sample}

The target group of the interviewed respondents was general nurses from two healthcare facilities. We distributed 100 questionnaires to healthcare facility $\mathrm{A}$ and 100 questionnaires to healthcare facility B. A total of 153 questionnaires were completed and returned. The return rate was (A: $71 \%, \mathrm{~B}: 82 \%$ ). A total of $76.5 \%$ of the 200 questionnaires were analyzed. The difference between the answers in research groups of the two medical facilities is summarized in Table 1.

The fundamental characteristics of the respondents of both compared medical facilities were expressed using the median $\mathrm{m}_{\mathrm{e}}$. The lower quartile $\mathrm{Q}_{25}$ and the upper quartile $\mathrm{Q}_{75}$ were also determined by the ordered selection, which helped establish the similarity or difference of both monitored groups. The minimum specified values $\mathrm{X}_{\text {min }}$, and the maximum specified values $\mathrm{X}_{\max }$ for the individual detected parameters were also given to complete the data sets. According to these calculated data, it could be stated that both groups were similar. The "respondents" average age was around 40 years, with a length of practice of 19 years in healthcare facility A, and an average age of 38 years and 12 years of practice in healthcare facility in Hospital B - which corresponded to the average year of completed medical education in both healthcare facil- 
Table 1. Characteristics of the research sample

\begin{tabular}{|c|c|c|c|c|c|c|}
\hline & \multicolumn{3}{|c|}{ Healthcare facility A; $n=71$} & \multicolumn{3}{|c|}{ Healthcare facility B; $n=82$} \\
\hline & $\mathrm{m}_{\mathrm{e}}\left(\mathrm{Q}_{25} ; \mathrm{Q}_{75}\right)$ & $\mathrm{X}_{\min }$ & $\mathrm{X}_{\max }$ & $\mathrm{m}_{\mathrm{e}}\left(\mathrm{Q}_{25} ; \mathrm{Q}_{75}\right)$ & $X_{\min }$ & $X_{\max }$ \\
\hline Age of respondents & $41(33 ; 48)$ & 22 & 60 & $38(31 ; 46)$ & 20 & 60 \\
\hline Length of experience given in years & $19(8 ; 28)$ & 1 & 43 & $12(5 ; 22)$ & 1 & 39 \\
\hline Year of completion of education & $1996(2006 ; 1987)$ & 2018 & 1977 & $2004(2013 ; 1992)$ & 2018 & 1977 \\
\hline Year of the last education in venous blood collecting & 2017 (2017; 2001) & 2018 & 1977 & 2007 (2016; 1995) & 2018 & 1977 \\
\hline
\end{tabular}

ities. Even though some general nurses stated that they had not been educated in venous blood collection since completing their nursing training in 1977, the average year of 2017 was more favorable for healthcare facility A.

\section{Results and discussion}

Given the large amount of data collected, the main results presented are for a group of questions focusing on identifying actions associated with the collection of venous blood.

The collection of venous blood and biological material is critical in issuing the correct laboratory result. The presented research took place in two hospitals that met the requirements for granting a certificate of quality and safety (according to CSN EN ISO 9001). Therefore, we assumed that the quality of specific procedures performed in these facilities would be at a high level and always in favor of the patient. The questionnaire was used to assess deviations from best practices in venous blood collecting. Most of the questions were answered by choosing from a four-point scale "never, rarely, often, and always". The answers of the respondents from both hospitals were very balanced, although not always correct. According to the respondents, the frequency of venous blood collecting activity is high in both healthcare facilities. In a healthcare facility A, $69 \%$ of respondents declared that they took venous blood daily and $28.2 \%$ weekly. In Hospital B, 22\% reported this activity daily and $47.6 \%$ weekly. One of the questions reveals the interest of general nurses in further education in proper venous blood collection - and their opinion on the importance of education. The answers agreed, but they were not satisfactory for us. According to respondents, more than a third of respondents (A: 29.6\%; B: 25.6\%) completely agree that they have enough information on venous blood collection procedures. Therefore, we were surprised that almost half of the respondents (A: 42.2\%; B: 47.6\%) do not want further education. We are aware that venous blood collection is one of the most common nursing interventions, and the collection itself is mainly a manual activity, so it depends on the knowledge and skills of the collection staff. It is also known that the human factor causes most health errors, and most of these errors can be prevented (Friedecký, 2010). Therefore, it would be desirable to arouse lifelong interest in general nurses who draw blood almost daily (Bölenius et al., 2013). According to our findings, the top management of both monitored hospitals fully supports the employees' lifelong education.

We obtained interesting information in the items associated with the verification of identity. Checking a patient's identity before taking venous blood has specific rules. The aim is to eliminate the risk of confusing patients in the provision of healthcare. According to the accreditation standards, JAK, o.p.s. (The Joint Accreditation Commission, SAK o.p.s. in Czech) (Marx and Vlček, 2014) and CSAH standards, s.r.o. (Czech Society for Accreditation in Healthcare, ČSAZ s.r.o. in Czech) (Podstatová, 2017) based on JCI (The Joint Commission International) standards, the patient must be identified in at least two ways: name and birth number, date of birth, identification bracelet, or photograph of the patient. The patient's room number or the label above his bed should not be used for identification purposes. The method of identification can be determined in a particular facility by an internal standardized nursing care procedure. Misidentification of a patient or sample could have serious consequences affecting clinical decision making and patient safety. The process of verifying the patient's identity is critical during all steps throughout the nursing process (Grissinger, 2014).

In both hospitals, general nurses stated that they always identified the patient by asking for a name and birth number or social security number (A: $39.4 \%$; B: 39.0\%). We have verified that process of indentification based on patients' birth or security number does not differ significantly ( $p$ 0.540). The higher frequency of responses was the choice to always identify the patient according to the identification bracelet (A: $59.1 \%$; B: $53.7 \%$ ). Despite the fact that the majority of nurses from both hospitals chose the answer "always", we have verified statistically different approaches in ID bracelet usage for a patient's identification ( $p$ 0.014), see Table 2. The majority of general nurses in Hospital A (76.1\%) stated that at the same time, they always check the nameplate at the patient's bedside. Surprisingly, $17.1 \%(n=14)$ of respondents from healthcare facility B stated that they did not have to identify the patient because they already knew him or her. This procedure must be considered unacceptable. An equally important factor in the correct implementation of the preanalytical phase is the designation of the sampling set. International guidelines and national operating procedures require tube labeling before venous blood sampling. Collection personnel should check patient identification information on collection tubes before performing the collection itself.

We found that the answers differed on whether the tube is labeled before collection through a questionnaire survey. Most nurses from hospital A, 63.4\%, stated that they always mark the collection tube before approaching the patient, but only $26.8 \%$ of hospital B respondents gave the same answer (we have verified the statistical differences in labeling the tube before approaching the patients - see Table 3). Respondents also responded differently to the possibility that they would always label the tube only after collection (A: $4.2 \%$; B: $26.8 \%$ ). Respondents also stated that the tube is always marked by someone else (A: 16.9\%; B: 6.1\%), and often a relatively large proportion of respondents (A: $32.4 \%$; B: $18.3 \%$ ) do so. However, the procedure for labeling a collection tube after collection, let alone someone else, is unacceptable. 
Table 2. Patient identification (selected answers) - How and how often do you check the identity of a patient when collecting venous blood samples?

\begin{tabular}{|c|c|c|c|c|c|c|c|c|c|c|c|}
\hline \multirow{2}{*}{ Hospital } & \multicolumn{2}{|c|}{ Never } & \multicolumn{2}{|c|}{ Seldom } & \multicolumn{2}{|c|}{ Often } & \multicolumn{2}{|c|}{ Always } & \multirow{2}{*}{ Total $(N)$} & \multirow{2}{*}{$\chi^{2}$} & \multirow{2}{*}{$p$} \\
\hline & $n(0)$ & $n(\mathrm{e})$ & $n(\mathrm{o})$ & $n(\mathrm{e})$ & $n(0)$ & $n(\mathrm{e})$ & $n(0)$ & $n(\mathrm{e})$ & & & \\
\hline A & 10 & 12.993 & 12 & 12.065 & 21 & 18.098 & 28 & 27.843 & 71 & 1.156 & \\
\hline B & 18 & 15.007 & 14 & 13.935 & 18 & 20.902 & 32 & 32.157 & 82 & 1.001 & 0.540 \\
\hline Total & 28 & 28.000 & 26 & 26.000 & 39 & 39.000 & 60 & 60.000 & 153 & 2.157 & \\
\hline \multicolumn{12}{|c|}{ I check the patient's photo ID/ID bracelet } \\
\hline \multirow{2}{*}{ Hospital } & \multicolumn{2}{|c|}{ Never } & \multicolumn{2}{|c|}{ Seldom } & \multicolumn{2}{|c|}{ Often } & \multicolumn{2}{|c|}{ Always } & \multirow{2}{*}{ Total $(N)$} & \multirow{2}{*}{$\chi^{2}$} & \multirow{2}{*}{$p$} \\
\hline & $n(\mathrm{o})$ & $n(\mathrm{e})$ & $n(\mathrm{o})$ & $n(\mathrm{e})$ & $n(\mathrm{o})$ & $n(\mathrm{e})$ & $n(\mathrm{o})$ & $n(\mathrm{e})$ & & & \\
\hline A & 8 & 10.673 & 6 & 10.673 & 15 & 9.745 & 42 & 39.908 & 71 & 5.659 & \\
\hline B & 15 & 12.327 & 17 & 12.327 & 6 & 11.255 & 44 & 46.092 & 82 & 4.900 & 0.014 \\
\hline Total & 23 & 23.000 & 23 & 23.000 & 21 & 21.000 & 86 & 86.000 & 153 & 10.559 & \\
\hline
\end{tabular}

Note: $n$ (o) - observed - empirical frequency / count; $n$ (e) - expected frequency / count. Expected frequency $=\left(\right.$ row total ${ }^{*}$ column total $) / N$.

Table 3. Test tube labeling (selected answers) - When do you label the test tube?

Before I approach the patient

\begin{tabular}{|c|c|c|c|c|c|c|c|c|c|c|c|}
\hline \multirow{2}{*}{ Hospital } & \multicolumn{2}{|c|}{ Never } & \multicolumn{2}{|c|}{ Seldom } & \multicolumn{2}{|c|}{ Often } & \multicolumn{2}{|c|}{ Always } & \multirow{2}{*}{ Total $(N)$} & \multirow{2}{*}{$x^{2}$} & \multirow{2}{*}{$p$} \\
\hline & $n(\mathrm{o})$ & $n(\mathrm{e})$ & $n(\mathrm{o})$ & $n(\mathrm{e})$ & $n(0)$ & $n(\mathrm{e})$ & $n(\mathrm{o})$ & $n(\mathrm{e})$ & & & \\
\hline A & 17 & 27.843 & 1 & 5.105 & 8 & 6.961 & 45 & 31.092 & 71 & 13.900 & \\
\hline B & 43 & 32.157 & 10 & 5.895 & 7 & 8.039 & 22 & 35.908 & 82 & 12.036 & $<0.001$ \\
\hline Total & 60 & 60 & 11 & 11 & 15 & 15 & 67 & 67 & 153 & 25.936 & \\
\hline
\end{tabular}

Alongside the patient before sampling

\begin{tabular}{|c|c|c|c|c|c|c|c|c|c|c|c|}
\hline \multirow{2}{*}{ Hospital } & \multicolumn{2}{|c|}{ Never } & \multicolumn{2}{|c|}{ Seldom } & \multicolumn{2}{|c|}{ Often } & \multicolumn{2}{|c|}{ Always } & \multirow{2}{*}{ Total $(N)$} & \multirow{2}{*}{$x^{2}$} & \multirow{2}{*}{$p$} \\
\hline & $n(0)$ & $n(\mathrm{e})$ & $n(\mathrm{o})$ & $n(\mathrm{e})$ & $n(\mathrm{o})$ & $n(\mathrm{e})$ & $n(\mathrm{o})$ & $n(\mathrm{e})$ & & & \\
\hline A & 40 & 42.229 & 13 & 12.993 & 11 & 8.817 & 7 & 6.961 & 71 & 0.658 & \\
\hline B & 51 & 48.771 & 15 & 15.007 & 8 & 10.183 & 8 & 8.039 & 82 & 0.570 & 0.746 \\
\hline Total & 91 & 91.000 & 28 & 28.000 & 19 & 19.000 & 15 & 15.000 & 153 & 1.228 & \\
\hline
\end{tabular}

Note: $n$ (o) - observed - empirical frequency / count; $n$ (e) - expected frequency / count. Expected frequency = (row total ${ }^{*}$ column total)/N.

The venous blood collection can be facilitated by placing the turnstile over the collection site when the vein dilates which becomes more palpable and visible. However, after venipuncture and verification of the first tube's filling, the turnstile must be released immediately. The "arm exercise" recommended in the past, is not currently recommended. Withdrawal of the limb for more than one minute and exercise of the arms increases the concentration of high molecular weight substances by up to $10 \%$, increases the concentration of some analytes by up to $20 \%$, and changes overall homeostasis (Loosová et al., 2018). More than half of the respondents (A: 69.0\%; B: 60.0\%) stated that they always remove the turnstile as soon as blood begins to flow into the first tube. We were also interested in how general nurses follow the correct order of tubes when taking venous blood to examine various laboratory analyses. The Czech Hematological society, CMA JEP (Czech Medical Association of J. E. Purkyně) issued a recommendation based on the CLSI standard (The Clinical and Laboratory Standards Institute), according to which the order of the tubes at collection is followed. The patient is first bled for blood cultures and a test tube for erythrocyte sedimentation. This is followed by a test tube for coagulation with sodium citrate, which should always be included second to exclude tissue factor admixture in the first tube. Next is a test tube for biochemical and serological examination, followed by the blood test tube and biochemical test with K3EDTA or K2EDTA. The last one is a test tube for glucose and lactate, which is to follow the order of taking samples to avoid contamination of the blood with the anticoagulant (Hrachovinová and Mikulenková, 2017).

From the answers of the general nurses of both healthcare facilities, it can be concluded that they either did not understand the question or are wrong in the collection of venous blood and do not correctly follow the order of different collection tubes with or without coagulation additives. More than half of the respondents (A: $56.3 \%$; B: $53.7 \%$ ) stated that they always take the first tubes with ingredients. These findings are also confirmed by practice. In the article in the information bulletin of the Czech Society of Clinical Biochemistry - which is intended for professionals in intensive care, laboratory and medical technology, computer technology, and clinical biochemistry - the author, who is a general nurse, describes the quality audit of biological material performed at her workplace in a home for the elderly. In this honest statement, she states that the tubes' correct order during collection is not taken into 
account in practice. The nurses do not know this order or, as the author states, do not address it (Benčíková, 2012). It is no less critical after venous blood collection to mix the blood carefully in the collection tubes. Mixing the blood with an anticoagulant will prevent the blood from clotting and allow it to be analyzed.

On the contrary, mixing the clotted blood collected in a plastic tube will facilitate and speed up the sample's coagulation. However, it is essential to mix the blood gently, turning it several times slowly. Excessive tube inversion is associated with a higher risk of hemolysis (Lima-Oliveira et al., 2013; Loosová et al., 2018). The percentage of answers to the question of handling and mixing blood can be considered satisfactory. More than half of general nurses (A: 76.1\%; B: 73.2\%) correctly stated that they gently mix the tubes by turning them several times after collection. Coagulation of blood collected in a test tube with an anticoagulant, caused by insufficient mixing of the sample immediately after collection, and hemolysis of serum caused by careless handling of the blood after collection are among the most common discrepancies in receiving the collected sample in the laboratory. Analytes that are already interfered with by mild hemolysis include, for example, potassium, liver, or cardiac enzymes. Of the total number of rejected laboratory samples, hemolysis accounts for up to $60 \%$. In $6 \%$ of these samples, strong hemolysis precludes any analysis (Jabor, 2008).

The analysis of the data showed that there was no statistically significant difference $(p>0.05)$ between the knowledge of the general nurses of both facilities $\mathrm{A}$ and $\mathrm{B}$ in the responses regarding patient identification before collection, correct use of a tourniquet for venous blood collection, or corresponding inversion of tubes after venous blood collection. The answers of the respondents of both healthcare facilities were balanced. A statistically significant difference $(p<0.05)$ was revealed in the procedures for labeling the collection kit before collection and adhering to the correct order of the different collection tubes with and without individual ingredients. In this case, the answers are more favorable for healthcare facility A.

According to many authors, errors caused by sampling and manipulation are the most common type of preanalytical errors. This manipulation may be a significant component of uncertainty for some analyses (Hawkins, 2012; Jabor and Franeková, 2012; 2013). Reporting adverse events, learning from others' mistakes, and implementing systemic measures to prevent further misconduct is one of the pillars of established quality in healthcare facilities. In 2007, researchers from the Institute of Medical Biological Sciences in Sweden conducted the first questionnaire survey on errors in the preanalytical phase in primary care. The study compared information retrieval, tube labeling, and test requirements management procedures in 70 primary care centers compared to the same procedures for staff in two clinical laboratories. The study showed that good practice was not always followed, and its practical recommendation was to set up a training program (Bölenius et al., 2014). In 2009-2010, an extensive training program for venous blood sampling procedures took place in Sweden. A study published in 2013 confirmed that although there was a slight improvement in preanalytical venous blood sampling procedures, the results were still unsatisfactory (Bölenius et al., 2013). Therefore, laboratory workers and phlebotomists subsequently created an extensive online e-learning program on preanalytical procedures, including a specific, practical lecture on venous blood collection. The results published by Swedish researchers were obtained annually in 2014-2017 (Willman et al., 2018). The number of staff performing venous blood sam- pling who always asked the patient for a name and birth number increased from $79.5 \%$ in 2007 to $86.5 \%$ in 2016 . In our questionnaire survey, almost $40 \%$ of respondents declared a corresponding procedure. In accordance with the recommended practice, foreign staff correctly stated that they would never not check the patient's identity because they already knew him - which did not change from 2007 to 2016. This response was still around $70 \%$. In our survey, respondents from both hospitals expressed themselves differently; $62.0 \%$ of respondents in Hospital A and $42.7 \%$ of Hospital B will never forget to check a patient's identity before collection. The responses from foreign employees who stated that they always mark the tube before or immediately after collection at the patient's bedside increased from $63.8 \%$ in 2007 to $86.9 \%$ in 2016 . In this case, according to the answers, the procedures in our healthcare facilities do not match. The majority of staff stated that they always mark the tube next to the patient before the actual collection (A: $9.9 \%$; B: $9.8 \%$ of the respondents). $85.7 \%$ of foreign respondents in 2007 correctly stated that someone else would never label a test tube collected by them. This response decreased to $74.9 \%$ in 2016 . In our study, the results are somewhat startling. Only $39.4 \%$ of general nurses in Hospital A (and 56.1\% in Hospital B) stated that someone else labelling a test tube after collection would never happen. It follows from the above that more than half of the respondents admit to the variant that the collected tube can be marked by someone else.

\section{Study limitations}

A potential study limitation is the size of the research sample. This could impact the final statistical results of the differential tests, which could have been different if the number of respondents was increased. The study makes use of a relatively homogeneous sample; from two similar size hospitals (similar number and types of departments, similar number of beds and staff).

\section{Conclusions}

The initial focus of laboratory staff only on the analytical process extends to the overall laboratory examination process, with regard to safe care for the benefit of the patient. The preanalytical laboratory phase covers all processes from the moment when the physician indicates the laboratory requirement until the moment when the sample is ready for the analysis itself. The condition for a correct result is the delivery of a quality sample to the laboratory. Faults that may occur during venous blood collection and subsequent manipulation are numerous, including inaccurate patient and sample identification, incorrectly selected sampling system and inappropriate sample amount, hemolysis interference, or improper handling of anticoagulant tubes. Errors associated with these procedures may not always be detected and may, therefore, compromise patient safety and lead to adverse events. The research revealed that the answers of the general nurses of both monitored healthcare facilities are statistically balanced but differ for particular items - and are not always correct. Procedures for proper venous blood collection are not always followed. The results are consistent with previous studies and clinical experience, confirming that monitoring venous blood collection procedures requires attention. Our sample's major problem is labeling the collection kit before blood collection, patient identification before the procedure, and correct use of a tourniquet for venous blood collection. Only a quarter of nurses in facility B mark the tubes before approaching the patient for blood collection. 


\section{Ethics and consent}

The relevant committees approved the study (the approval does not include the IRB number from the ethics committee, which is common practice in the hospitals involved). All of the respondents were informed of their voluntary participation in the research study. The questionnaires were stored in a locked space, and all data were decoded. Only the researchers had access to the codes and the corresponding names. Participants were assured confidentiality by the information letter and could withdraw from the survey without declaring a reason. They were also informed that data would be presented at the group level only.

\section{Conflict of interests}

The authors declare no potential conflict of interests with respect to the research, authorship, and/or publication of this article.

\section{Acknowledgements}

We would like to thank Professor Karin Bölenius from the Department of Nursing, Umeå University in Sweden, for providing a questionnaire and supporting study materials on the subject of our research. We thank all the nurses for their support and collaboration in filling out the questionnaires.

\title{
Dotazníková studie: Proces a management kvality v preanalytické fázi laboratorního vyšetření na oddělení spojených laboratoří
}

\author{
Souhrn \\ Úvod: Příprava pacienta k vyšetření a odběr biologického materiálu patří mezi kritické faktory kvality preanalytické fáze. Odběr \\ krve zároveň patří mezi běžné a základní ošetřovatelské intervence. \\ Metodika: Realizována byla dotazníková studie s využitím obsahově validovaného dotazníku z laboratoře klinické biochemie Uni- \\ verzitní nemocnice v Umeå ve Švédsku. Analýza dat byla provedena s využitím programu Statistika 12 na hladině významnosti \\ 0,05 . \\ Cíl: Cílem bylo zhodnotit znalosti vybraného souboru všeobecných sester o správném postupu odběru venózní krve ve dvou akre- \\ ditovaných lůžkových zdravotnických zařízeních. \\ Výsledky: Studie se účastnilo celkem 153 všeobecných sester ze dvou lůžkových zařízení (nemocnice A: $n=71$; nemocnice B: \\ $n=82$ ). Odpovědi sester $\mathrm{z}$ obou zařízení byly obdobné, ale ne vždy správné. Zjištěny byly statisticky významné rozdíly $(p<0.05)$ \\ ve znalostech o procesu odběru venózní krve, zejména $v$ deklarovaném označování zkumavek před odběrem krve a v odpovědích \\ o správném pořadí zkumavek při odběru více zkumavek najednou $(p<0.05)$. \\ Závěr: Odhalené rozdíly ve znalostech a zvyklostech při odběru venózní krve potvrzují zjištění z předchozích zahraničních studií. \\ Pro zajištění kvalitnější péče je nezbytná úzká spolupráce všeobecných sester s pracovníky klinických laboratoří a potřeba kontro- \\ ly v preanalytické fázi odběru vzorků biologického materiálu.
}

Klíčová slova: bezpečnost pacientů; odběr venózní krve; preanalytická fáze; riziko zdravotní péče; všeobecná sestra

\section{References}

1. Benčíková M (2012). Audit kvality odběrů biologického materiálu v domově pro seniory. FONS. Pardubice: STAPRO, s. r. o. 27(4): 19.

2. Bölenius K, Brulin C, Graneheim UH (2014). Personnel's experiences of phlebotomy practices after participating in an educational intervention programme. Nurs Res Pract 2014: 538704. DOI: $10.1155 / 2014 / 538704$.

3. Bölenius K, Brulin CH, Grankvist K, Lindkvist M, Söderberg J (2012). A content validated questionnaire for assessment of self reported venous blood sampling practices. BMC Res Notes 5: 39. DOI: 10.1186/1756-0500-5-39

4. Bölenius K, Lindkvist M, Brulin CH, Grankvist K, Nilsson K, Söderberg J (2013). Impact of a large-scale educational intervention program on venous blood specimen collection practices. BMC Health Services Research 13: 463. DOI: 10.1186/1472-6963-13-463.

5. Fang L, Fang S-H, Chung Y-H, Chien S-T (2008). Collecting factors related to the haemolysis of blood specimens. J Clin Nurs 17: 2343-2351. DOI: 10.1111/j.1365-2702.2006.02057.x

6. Friedecký B (2010). Kvalita v klinické laboratoři a bezpečnost pacientů. Klin Biochem Metab 18(39): 136-143.

7. Friedecký B (2018). Aktuální sdělení z oblasti preanalytické fáze. FONS. Pardubice: STAPRO, s. r. o. 28(3): 12.

8. Grissinger M (2014). Oops, Sorry, Wrong Patient! A Patient Verification Process is Needed Everywhere, Not Just at the Bedside. P \& T: a Peer-Reviewed Journal for Formulary Management 39(8): 535-537.
9. Hawkins R (2012). Managing the pre-and post-analytical phases of the total testing process. Ann Lab Med 32(1): 5-16. DOI: 10.3343/alm.2012.32.1.5.

10. Hrachovinová I, Mikulenková D (2017). Pořadí zkumavek při odběru krve. Doporučení laboratorní sekce České hematologické společnosti ČLS JEP. [online] [cit. 2020-06-07]. Available from: https://www.hematology.cz/doporuceni/laboratorni_sekce/ files/obecna/Doporuceni_LS_CHS_CLS_JEP-Poradi_odberu_ v01.pdf

11. Jabor A (2008). Vnitřní prostředí. Praha: Grada Publishing, $560 \mathrm{p}$.

12. Jabor A, Franeková J (2012). Několik poznámek k postanalytické fázi a bezpečnosti pacientů. FONS. Pardubice: STAPRO, s. r. o. 22(4): 18.

13. Jabor A, Franeková J (2013). Principy interpretace laboratorních testů. Praha: Roche s.r.o., Diagnostics Division, $381 \mathrm{p}$.

14. Kratochvíl J, Plzák Z, Peková A (2013). ČSN EN ISO 15189 Zdravotnické laboratoře - Požadavky na kvalitu a způsobilost. Praha: Úrad pro technickou normalizaci, metrologii a státní zkušebnictví. [online] [cit. 2020-06-07]. Available from: https:// library.upol.cz/arl-upol/cs/detail-upol_us_cat-0180194-cSNEN-ISO-15189-Zdravotnicke-laboratore-Pozadavky-na-kvalitua-zpusobilost $/$ ?disprec $=4$ \&iset $=1$

15. Lima-Oliveira G, Lippi G, Salvagno GL, Montagnana M, Gelati M, Volanski W, et al. (2013). Effects of vigorous mixing of blood vacuum tubes on laboratory test results. Clin Biochem 46(3): 250-254. DOI: 10.1016/j.clinbiochem.2012.10.033.

16. Loosová J, Malina P, Malinková M, Válek T, Vorlíčková H (2018). Pracovní postup preanalytické fáze laboratorního 
vyšetření krve. NCO NZO Brno. [online] [cit. 202006-07]. Available from: https://www.nconzo.cz/ file/742a62c0527209d37ff15a36d4ac4665518f6b2c

17. Lundberg GD (1990). Critical (panic) value notification: An established laboratory practice policy (parameter). JAMA 263(5): 709. DOI: 10.1001/jama.1990.03440050103044.

18. Marx D, Vlček F (2014). Akreditační standardy pro nemocnice. Praha: Spojená akreditační komise ČR, o.p.s., 168 p.

19. Plebani $\mathrm{M}$ (2009). Exploring the iceberg of errors in laboratory medicine. Clin Chim Acta 404: 16-23. DOI: 10.1016/j. cca.2009.03.022.

20. Podstatová R (2017). Hodnocení kvality a bezpečí lůžkové zdravotní péče. Česká společnost pro akreditaci s.r.o. [online] [cit. 2020-06-07]. Available from: http://www.csaz.cz/
dokumenty/Hodnotici_standardy_a_ukazatele_kvality_a_ bezpeci-2017.pdf

21. Rana SV (2012). No Preanalytical Errors in Laboratory Testing: A Beneficial Aspect for Patients. Ind J Clin Biochem 27: 319-321. DOI: 10.1007/s12291-012-0271-2.

22. Sciacovelli L, Plebani M (2009). The IFCC Working Group on laboratory errors and patient safety. Clin Chim Acta 404: 79-85. DOI: 10.1016/j.cca.2009.03.025.

23. Willman B, Grankvist K, Bölenius K (2018). Evaluation of the clinical implementation of a large-scale online e-learning program on venous blood specimen collection guideline practices. Clin Chem Lab Med (CCLM) 56(11): 1870-1877 DOI: 10.1515/CCLM-2018-0051. 